\title{
Planning model for the development and construction of thermal power plants using alternative fuels with optimal investment distribution
}

\author{
Nadiia Yushchenko ${ }^{1, *}$ \\ ${ }^{1}$ Khmelnytskyi National University, 11 Instytuts `ka str., 29016 Khmelnytskyi, Ukraine
}

\begin{abstract}
The work is devoted to the analysis of the current state and prospects of modernization of the fuel and energy complex and investments in renewable energy in order to achieve the Sustainable Development Goals in Ukraine, adaptation of an economic and mathematical model adequate to this process, allowing for rational distribution of investments, which in Ukraine plans to attract to development of the energy system and renewable energy as part of the implementation of the strategy "Vectors of Economic Development 2030", the collection of potential sources of funds for the development and construction of thermal power plants using alternative fuels on the basis of existing heat supply enterprises in Ukraine. In the article it is recommended to use the add-in "Search for a solution" MS Excel for performing calculations according to the proposed deterministic model of a partially integer linear programming problem with boolean variables. As a result of the implementation of the proposed approach, moderate protection of the main producers (network operators) - heat supply utilities will be provided and market conditions for independent producers will be created, the operator will be encouraged to increase the efficiency of its own production.
\end{abstract}

\section{Introduction}

Energy today is the largest industry in the world and an industry that is experiencing an unprecedented breakthrough in our era, when there is an exponential explosive (non-linear) growth in renewable energy. The energy singularity will come when renewables displace fossil fuels and provide almost all the energy for our civilization [1].

Ensuring shared access to affordable, reliable and modern energy by 2030, significantly increasing the share of renewable energy in the global energy mix, doubling the global rate of improvement in energy efficiency, encouraging investment in energy infrastructure and clean energy technologies, expanding infrastructure and modernizing technologies for modern and sustainable energy supply in developing countries, taking into account their

* Corresponding author: nadezhda15yu@gmail.com 
respective support programs, are the main objectives of Goal 7 of the global Strategy for Sustainable Development until 2030 [2, pp. 20-21 ].

In accordance with the Monitoring Report [3] developed by the State Statistics Service of Ukraine with the support of UNICEF in Ukraine, containing information on the status of achieving the Sustainable Development Goals by national SDG indicators [4] during 20152019 (Table 1) most of the electricity in Ukraine, except for nuclear power plants (52$56 \%)$, was produced by thermal power plants $(29-32 \%)$. The share of alternative energy sources increased from 1\% in the total production in 2015 to $4 \%$ (5.5 billion $\mathrm{kWh}$ ) in 2019.

Table 1. Dynamics of the structure of electricity production in Ukraine.

\begin{tabular}{|c|c|c|c|c|c|c|c|c|c|c|}
\hline & \multicolumn{2}{|c|}{2015} & \multicolumn{2}{c|}{2016} & \multicolumn{2}{c|}{2017} & \multicolumn{2}{c|}{2018} & \multicolumn{2}{c|}{2019} \\
\cline { 2 - 11 } & $\begin{array}{c}\text { billion } \\
\mathrm{kWh}\end{array}$ & $\%$ & $\begin{array}{c}\text { billion } \\
\mathrm{kWh}\end{array}$ & $\%$ & $\begin{array}{c}\text { billion } \\
\mathrm{kWh}\end{array}$ & $\%$ & $\begin{array}{c}\text { billion } \\
\mathrm{kWh}\end{array}$ & $\%$ & $\begin{array}{c}\text { billion } \\
\mathrm{kWh}\end{array}$ & $\%$ \\
\hline $\begin{array}{c}\text { Electricity } \\
\text { production, } \\
\text { total }\end{array}$ & 157.7 & 100 & 154.8 & 100 & 155.4 & 100 & 159.4 & 100 & 154.0 & 100 \\
\hline including & & & & & & & & & & \\
\hline $\begin{array}{c}\text { Condensing } \\
\text { power plants of } \\
\text { generating } \\
\text { companies }\end{array}$ & 49.4 & 31 & 49.9 & 32 & 45.0 & 29 & 47.8 & 30 & 44.9 & 29 \\
\hline $\begin{array}{c}\text { Thermal power } \\
\text { plants (TPP) \& } \\
\text { cogeneration } \\
\text { units }\end{array}$ & 6.1 & 4 & 6.7 & 4 & 10.9 & 7 & 11.0 & 7 & 10.9 & 7 \\
\hline $\begin{array}{c}\text { Hydraulic } \\
\text { power plants }\end{array}$ & 5.2 & 3 & 7.5 & 5 & 9.0 & 6 & 10.4 & 7 & 6.5 & 4 \\
\hline $\begin{array}{c}\text { Hydroelectric } \\
\text { power plants }\end{array}$ & 1.6 & 1 & 1.6 & 1 & 1.6 & 1 & 1.6 & 1 & 1.3 & 1 \\
\hline $\begin{array}{c}\text { Nuclear power } \\
\text { plants }\end{array}$ & 87.6 & 56 & 81.0 & 52 & 85.6 & 55 & 84.4 & 53 & 83.0 & 54 \\
\hline Blockstations & 6.2 & 4 & 6.6 & 4 & 1.5 & 1 & 1.5 & 1 & 1.8 & 1 \\
\hline $\begin{array}{c}\text { Alternative } \\
\text { energy sources } \\
\text { (wind power } \\
\text { plants, solar } \\
\text { power plants, } \\
\text { biomass) }\end{array}$ & 1.6 & 1 & 1.6 & 1 & 1.9 & 1 & 2.6 & 2 & 5.5 & 4 \\
\hline
\end{tabular}

Source: compiled by the author based on data [3, p. 42]

Reduce the carbon footprint of the fuel and energy complex, attract $\$ 10$ billion in investments in renewable energy, reduce the share of coal generation, ensure an increase in the share of biomass in heat production up to $30 \%$, form the share of generation from renewable energy sources in total electricity production at $25 \%$ - these are the strategic goals of the "Energy" direction of the National Economic Strategy 2030 [5].

The share of energy generated from renewable sources in total final energy consumption in 2019 compared to 2015 increased by $62 \%$ (Fig. 1), but below the target of $11 \%$ set for 2020 , by $26 \%$ despite on the fact that increasing the share of energy from renewable sources in the national energy balance, in particular by introducing additional capacities of facilities that generate energy from renewable sources, is task 7.3 of Sustainable Development Goal 7 for Ukraine [6]. With a 90\% probability, it can be argued that in 2021, while maintaining the emerging trend described by the polynomial model of the $2 \mathrm{nd}$ degree, the share of energy produced from renewable sources in the total final energy consumption in Ukraine will be at least $8.8 \%$ but will not exceed $9.9 \%$. 


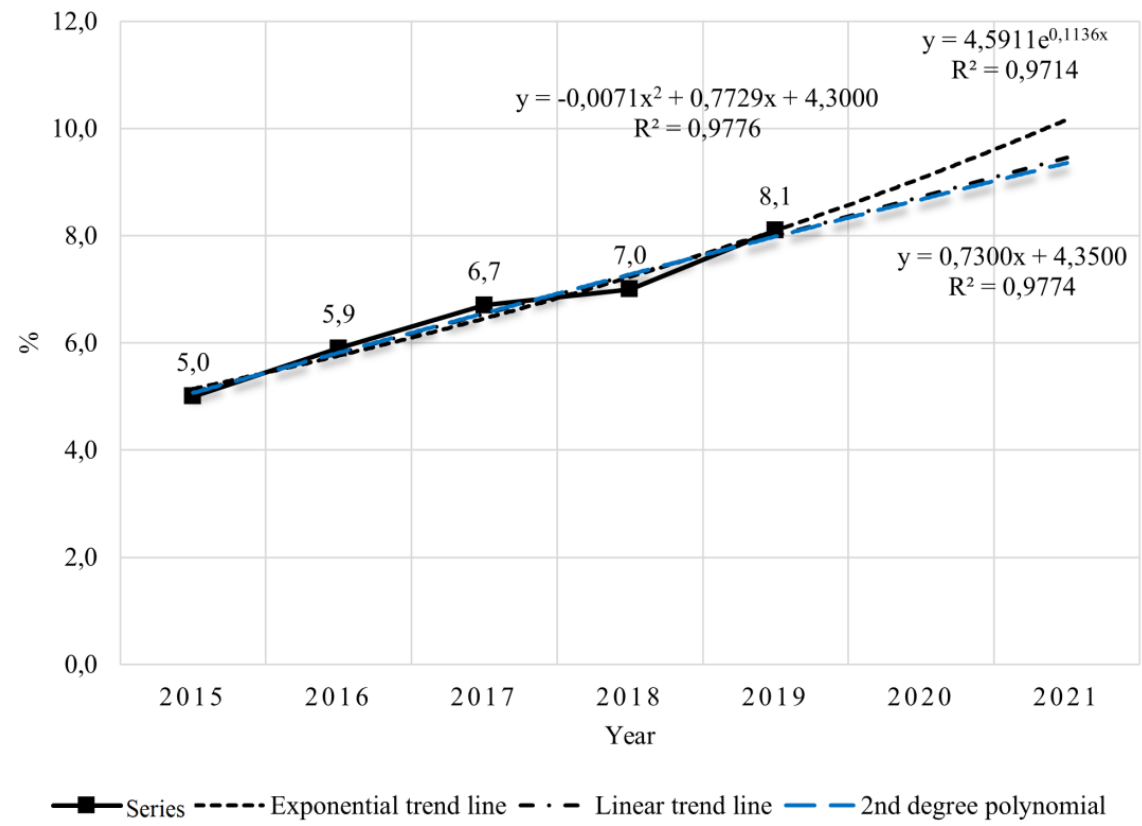

Fig. 1. Dynamics of the share of energy produced from renewable sources in the total final energy consumption in Ukraine.

Physically and morally obsolete fixed assets and technologies, renewing at an extremely slow pace, negatively affect the performance of functioning, the quality and cost of utilities, lead to cost overruns of resources at all stages of production, transportation and delivery to end users. Losses from energy conversion in Ukraine reach 38471 thousand tons of oil equivalent (accounting for $41 \%$ of the total energy supply). Losses during transportation and distribution of electricity $-14.8 \%$ and heat energy $-14.05 \%$, which is associated with the critical state of the infrastructure for transportation and distribution, as well as its technological structure, designed for a significantly larger volume of consumption [5]. According to the Ministry of Development of Communities and Territories of Ukraine, heat losses in heating networks (data are being developed since 2020) reach 20.4\% [3].

The rapid growth of renewable energy sources and a high level of wear and tear of thermal generation (stations have worked for an average of 50 years, a significant part of the infrastructure of thermal communal energy, heating networks has significantly exhausted its resource and is in an emergency state) in Ukraine leads to a reduction in a large number of power units TPP. To develop a set of methodological, scientific, technical and organizational foundations for a significant improvement of territorial heat supply systems and its practical application for: ensuring the stable and reliable functioning of communal heat power engineering with the supply of heat to consumers in the required quantity and proper quality for hot water supply and heating, taking into account domestic operating conditions equipment; replacement and savings at housing and communal services enterprises of up to $30 \%$ of natural gas relative to the basic costs in the first 5 years with a payback period of the proposed newest technological and technical measures up to 4-5 years; the use of mainly domestic modern devices and only in the absence of them foreign ones; replacement of outdated equipment, provided that it is impossible to increase the efficiency of its use with the help of modern technologies; the functioning of centralized and individual heat supply systems with the priority development of the first, the State target program for the modernization of communal heat power engineering was focused [7]. 


\section{Methods}

The adoption of rational and effective management decisions is impossible without a comprehensive analysis of the complex of interdependent factors, determination and comparative assessment of possible alternatives and acceptable action plans. Modeling is the only way so far to establish the potential consequences of alternative solutions, allowing them to be objectively compared, as well as to see options in perspective. The use of modern information technologies and economic and mathematical models and methods that simultaneously take into account all economic and physical conditions and find the best option during the modernization of energy facilities in Ukraine can become one of the components of the formation of a support system for the implementation of the latest regulation systems to ensure the development of the energy sector of Ukraine in the context of a circular economy and waste management, will ensure that decisions are made in favor of energy supply systems that are most beneficial for ensuring energy consumption in terms of safety, reliability, quality of energy supply and provision of energy services that are affordable and attractive in terms of environmental impact.

Scientific research F. Alobaid, N. Mertens, R. Starkloff, C. Heinze, B. Epple [8] and other scientists are devoted to the development of dynamic modeling of thermal power plants. R. de Freitas, E. Vogel, A. Korzenowski and L. Oliveira Rocha [9] a probabilistic model for supporting decision-making regarding investments in renewable energy was created. The work of E. Spyrou, B. Hobbs, M. Bazilian and D. Chattopadhyay [10] focuses on planning energy systems in fragile and conflict-affected states. A series of studies focused on the development of mathematical models of subsections of thermal power plants was carried out by A. Ghaffari, A. Chaibakhsh, S. Shahhosseini [11]. However, further formation and development requires economic and mathematical decision support tools for complex systems and capital-intensive projects, which allow the subject of management to increase the efficiency of decision-making through modeling and automation of information procedures.

The main goal of this work is to analyze the current state and prospects of modernizing the fuel and energy complex and investments in renewable energy to achieve the Sustainable Development Goals in Ukraine, adapting an economic and mathematical model that is adequate to this process, allowing for a rational distribution of investments, as well as collecting potential sources of funds for development and construction of thermal power plants using alternative fuels on the basis of existing heat supply enterprises in Ukraine.

\section{Results}

On the path of further development and implementation of European legislation in Ukraine, the policy of the state, relevant ministries, local authorities and manufacturers should be aimed at implementing Directive 2012/27EU [12] on the development of highly efficient cogeneration and efficient district heating and cooling from waste heat and renewable energy sources. Even in the future, there is no talk of a complete refusal of thermal communal energy from the use of natural gas. We can talk about its partial replacement by another energy carrier, which would be cheaper than gas, available for use and inexhaustible from the point of view of predetermined volumes of use. Such as, for example, waste from the timber processing industry, agriculture and the agro-industrial complex or garbage from landfills in Ukraine, the calorific value of 1 ton of which is about $1.6 \mathrm{Gcal} /$ ton [13], the processing of which will solve two problems at once: environmental (sorting and disposal of household waste) and energy (actually a source of non-fossil energy and reducing the cost of heat tariffs). 
The use of alternative fuels (co-processing) saves huge reserves of gas and coal, as well as reduces $\mathrm{CO}_{2}$ emissions. Moreover, Ukraine has set a stimulating tariff for heat "not from gas", as well as one of the world's highest "green" tariffs for electricity from biomass and biogas, namely 12.4 eurocents/kWh.

Among the advantages of waste disposal, the following should be noted. First, the energy utilization of waste will allow to reduce the area of landfills, where the main volume of the so-called "tailings" - the remains of municipal waste after the extraction of useful fractions from them - is now received. Secondly, energy utilization is the ability to utilize waste that is unsuitable for recycling. In addition, there are negative health and environmental impacts from recycling certain types of waste [14].

Efficient District Heating and Cooling - a district heating or cooling system that uses a minimum of $50 \%$ renewable energy, $50 \%$ waste heat, $75 \%$ heat from cogeneration, or a $50 \%$ combination of such energy and heat.

The construction of a TPP or mini TPP on waste is an excellent solution that will allow using waste from all enterprises of the woodworking industry (pulp and paper mills, plywood, sawmills), as well as agricultural and livestock waste as fuel.

The most promising and economically feasible step in Ukraine is the construction of a TPP using alternative fuels based on existing heat supply enterprises. This approach will make it possible to protect utilities from new independent producers in the area of TPP and maintain their position in the market [15].

To solve this problem, it is necessary to take into account all possible options for the development of existing enterprises, as well as available projects for the introduction of new enterprises. The choice of specific options for the development and placement of enterprises is carried out taking into account the volume of investment resources that can be used to support and increase production capacity. The criterion of optimality can be the requirement to minimize the necessary total aggregate investment costs, costs of manufacturing products and their transportation to consumers [16].

The economic and mathematical model of the problem of planning the development and construction of TPPs using alternative fuels based on existing heat supply enterprises with an optimal distribution of investment resources has the form:

$$
\begin{gathered}
v=e \sum_{i=1}^{m} \sum_{j=1}^{n_{i}} I_{i j} x_{i j}+\sum_{i=1}^{m} \sum_{j=1}^{n_{i}} c_{i j} y_{i j}+\sum_{i=1}^{m} \sum_{k=1}^{p} d_{i k} z_{i k} \rightarrow \min \\
\left\{\begin{array}{c}
\sum_{j=1}^{n_{i}} x_{i j}=1, i=\overline{1 ; m} \\
\sum_{i=1}^{m} \sum_{j=1}^{n_{i}} I_{i j} x_{i j} \leq R, \\
0 \leq y_{i j} \leq N_{i j} x_{i j}, i=\overline{1 ; m}, j=\overline{1 ; n_{l}} \\
\sum_{j=1}^{n_{i}} y_{i j}=\sum_{k=1}^{p} z_{i k}, i=\overline{1 ; m} \\
\sum_{i=1}^{m} z_{i k} \geq b_{k}, k=\overline{1 ; p}, \\
x_{i j} \in\{0 ; 1\}, i=\overline{1 ; m}, j=\overline{1 ; n_{l}}, z_{i k} \geq 0, i=\overline{1 ; m}, k=\overline{1 ; p},
\end{array}\right.
\end{gathered}
$$

where the known quantities (uncontrollable parameters) are:

$i$ - company number, existing or projected $(i=\overline{1 ; m})$;

$j$ - number of the development variant of the i-th enterprise $\left(j=\overline{1 ; n_{l}}\right)$;

$N_{i j}$ - production capacity of the $i$-th enterprise, subject to its development according to the $j$-th option;

$I_{i j}$ - investment costs required for the implementation of the $j$-th development option at the $i$-th enterprise;

$R$ - the maximum possible amount of investment costs that will be aimed at ensuring the development of all enterprises; 
$e$ - standard coefficient of economic efficiency of investments (discount rate);

$c_{i j}$ - the cost of a unit of production produced at the $i$-th enterprise, subject to its development according to the $j$-th option;

$k$ - product consumer number $(k=\overline{1 ; p})$;

$b_{k}-$ demand for products from the $k$-th consumer;

$d_{i k}-$ costs of transporting a unit of production along the route from the $i$-th enterprise to the $k$-th consumer.

Unknowns are:

$x_{i j}-$ logical variable reflecting the fact of the choice for the implementation of the $j$-th development option of the $i$-th enterprise

$$
x_{i j}=\left\{\begin{array}{c}
1 \text { if the } i \text {-th enterprise will develop on the } j \text {-th variant, } \\
0 \text { otherwise; }
\end{array}\right.
$$

$y_{i j}$ - the volume of production at the $i$-th enterprise in accordance with the $j$-th variant of its development;

$z_{i k}$ - the volume of transportation of products along the route from the $i$-th enterprise to the $k$-th consumer;

$v$ - total aggregate costs of investment, production and transportation of products.

The above mathematical model is a partially integer linear programming problem with boolean variables. It can be solved using the "Search for a solution" add-on of the MS Excel package for the implementation of deterministic models, including an analysis of the sensitivity of the solution to changes in the restrictive conditions.

Increasing the efficiency of their own heat-generating capacities, introducing more efficient technologies, switching to cheaper energy sources and types of fuel can be a worthy response from district heating utilities to the emergence of competition. Obviously, this will not happen in a year or two, but in the future it should happen, which is confirmed by the experience of introducing such systems in a number of European countries.

The introduction of alternative energy sources at the present stage of Ukraine's development is hampered by the high cost of design and equipment for the development of alternative energy sources, the development of alternative energy, which is completely dependent on imported equipment, the lack of proper regulatory framework for the development of the renewable sources market, corruption influence monopolies hindering the development of the investment market for clean technologies.

\section{Discussion}

Certain preconditions have been created in Ukraine for attracting funds from international financial, credit and donor organizations in order to successfully reform and modernize the housing and communal services and its infrastructure in cities. At the same time, the weak activity of municipalities, low executive discipline, administrative barriers and a high level of corruption impede the implementation of these projects at the proper level, despite the significant number of international donors and financial institutions in the system of financing capital projects in the field of housing and communal services. According to the National Institute for Strategic Research, the total disbursement rate for projects averages $30 \%$, and the deadlines for the implementation of most projects are 2020 and 2021. At the end of these terms, projects will be completed and unselected funds will be canceled [17].

The main direction of state policy in the direction of implementing measures aimed at energy conservation, energy efficiency and obtaining energy from alternative sources in Ukraine should be the creation of a comprehensive, consistent and flexible system of financial incentives. 
In the context of the decentralization reform, municipalities received additional rights regarding the organization of heat and energy supply systems, as well as financial instruments for their modernization. Provided that the management of public utilities is efficiently organized, this allows for a gradual transition to systems that have demonstrated high efficiency in European countries. The defining principles of their functioning is the role of municipalities planning the development of heat supply in urban agglomerations, contributing to the development of various forms of municipal-private partnerships to attract innovative investment in the industry, exercising control and coordination of the development of district heating systems and, in most cases, holding a controlling stake shares of corporate participants in the local heat supply market, which guarantees the rights of consumers to high-quality and uninterrupted services.

The formation of a modern industrial base for behavior with waste should be not only an important component of state and regional environmental policy, but also one of the priorities for decentralization of power and reform of local self-government.

Recycling waste in the direction of improving the quality of life and caring for the environment is not cheap, therefore, within the framework of international technical assistance, Ukraine should also consider the issue of its reorientation from research to increasing the investment share and environmental conversion of a part of external debt (debt-for-environment swap [18, pp. 113-114]), since Ukraine, after signing the Association Agreement with the EU [19], must implement the norms of European legislation, which requires an increase in funding. Environmental conversion provides for the possibility of transforming part of the obligations on the external public debt into the country's obligations to finance environmental protection measures on its own territory in the national currency for an agreed amount. This eco-conversion was carried out in Poland, Bulgaria and other countries.

\section{References}

1. Cordeiro, J. (2020). Rules for the future of energy: key theses in the Energy Transformation event. DTEK. https://dtek.com/energy-transition/index.html

2. UN General Assembly. (2015). Transforming our world: The 2030 Agenda for Sustainable Development A/RES/70/1. http://sdg.org.ua/images/Agenda2030.pdf

3. UNICEF. (2021). SDG Ukraine Monitoring Report 2020. https://www.unicef.org/ukraine

4. Cabinet of Ministers of Ukraine. (2019). Issues of data collection for monitoring the implementation of the Sustainable Development Goals (Order № 686-r). https://zakon.rada.gov.ua/laws/show/686-2019-\%D1\%80\#Text

5. Cabinet of Ministers of Ukraine. (2020, 6 November). Vectors of economic development 2030. Platform of the Center for Economic Recovery. https://nes2030.org.ua/\#rec246061582

6. United Nations in Ukraine. (2018). Sustainable Development Goals in Ukraine. http://sdg.org.ua/ua

7. Paton, B., Dolinsky, A., Basok, B., \& Bazeev, E. (2012). The project of the state target program of modernization of communal heat energy for 2012-2016 is an innovative basis of technological updating of systems of heat supply of settlements of Ukraine. Bulletin of the NAS of Ukraine, (9), 14-28. http://dspace.nbuv.gov.ua/handle/123456789/38993 
8. Alobaid, F., Mertens, N., Starkloff, R., (...), Heinze, C., \& Epple, B. (2017). Progress in dynamic simulation of thermal power plants. Progress in Energy and Combustion Science, (59), 79-162.

9. de Freitas, R.A., Vogel, E.P., Korzenowski, A.L. \& Oliveira Rocha, L.A. (2020). Stochastic model to aid decision making on investments in renewable energy generation: Portfolio diffusion and investor risk aversion. Renewable Energy. (to be published)

10. Spyrou, E., Hobbs, B.F., Bazilian, M.D. \& Chattopadhyay D. (2019). Planning power systems in fragile and conflict-affected states. Nature Energy, 4(4), 300-310.

11. Ghaffari, A., Chaibakhsh, A., \& Shahhosseini, S. (2012). Neuro-Fuzzy Modeling of Heat Recovery Steam Generator. International Journal of Machine Learning and Computing. 604-608. http://www.ijmlc.org/papers/198-L157.pdf

12. Directive 2012/27/EU of the European Parliament and of the council of 25 October 2012 on energy efficiency. (2012). Official Journal of the European Union.

13. Poltava Regional Municipal Production Enterprise of Heat Management "Poltavateploenergo". (2021). Environmental friendliness, efficiency, energy selfsufficiency: "Poltavateploenergo" on the way to effective transformations.

14. Lafarge Holcim. (2020). Five years on alternative fuels. https://lafargeholcimrus.ru/press-center/publications/2020/pyat-let-na-alternativnomtoplive

15. Yushchenko, N. (2021). Economic feasibility of development of a moderately liberalized thermal energy market in Ukraine. Economy and society, (23). https://doi.org/10.32782/2524-0072/2021-23-21

16. Yushchenko, N. (2019). Economic and mathematical tools for planning the development and location of waste processing enterprises in Ukraine. Problems and prospects of economics and management, 1(17), 96-106. http://ppeu.stu.cn.ua/article/view/176588

17. National Institute for Strategic Studies. (2019, 19 August). Analysis of the implementation of investment projects of international financial institutions in Ukraine revealed problems of their implementation: the opinion of the NISS expert.

18. Millennium Development Goals Ukraine: 2000-2015. (2015). National report. Kyiv, 125. http://un.org.ua/images/stories/docs/2015_MDGs_Ukraine_Report_ukr.pdf

19. Verkhovna Rada of Ukraine. (2015, 30 November). Association Agreement between Ukraine, of the one part, and the European Union, the European Atomic Energy Community and their Member States, of the other part. http://zakon2.rada.gov.ua/laws/show/984_011 